\title{
InfoNorth
}

\section{Canada's Crisis in Arctic Science: The Urgent Need for an Arctic Science and Technology Policy; Or, "Why Work in the Arctic? No One Lives There"}

\author{
By John H. England, Arthur S. Dyke and Gregory H.R. Henry
}

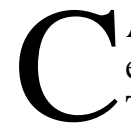

ANADA has entered a deep crisis in Arctic science. The lack of a formal Arctic Science and Technology Policy has left our highly fragmented efforts in Arctic research exceedingly vulnerable during times of financial stress and left us effectively without a voice. Logistical support, essential for operating in our vast northern territory, has all but disappeared as a facilitator for both government and university research. Within two years, only specially funded research will be possible, and opportunities for new careers will continue to plummet. The Arctic science community must alert the government to take action. If nothing is done to secure its future, Canada's capacity to perform Arctic research will collapse.

\section{OUR PERSPECTIVE}

The perspective we take here arises from acknowledging the following: (1) the results of the Federal Program Review, which brought Arctic research to its present crisis, are a fait accompli; government will not revisit these decisions; (2) therefore, to find a solution, we require a proposal that is politically supportable; (3) statements very supportive of Arctic research can be read in recent parliamentary documents; and (4) the downsizing of federal science occurred despite the mustering of the best arguments available by many dedicated science managers in support of the value of science; apparently these arguments are not, in themselves, sufficient to achieve high priority for science, especially for Arctic science, within the federal public service. Hence, rebuilding the arguments in support of Arctic science here is unlikely to take us forward.

We feel that we are facing a social issue, a shortfall of effective public support for Canadian science, which includes the research community. We also identify a structural issue for Arctic science, centred on the lack of an Act of Parliament that defines the value of Arctic research to the nation and secures its necessary infrastructure. What follows is neither a scientific paper nor a scholarly review of science policy or Arctic science history. Others are better placed to produce these, or have already done so (see
Adams et al., 1987). We speak here as active Arctic scientists who are alarmed by the rapid and continuing erosion of northern research in Canada, and who wish to highlight this crisis, draw instructive contrasts with recent U.S. initiatives, and offer, for discussion, a possible solution in light of current Canadian circumstances. Our essay seeks to make it clear that, if corrective action is not taken, Canadian Arctic science will shrivel to insignificance.

\section{WHERE WE ARE}

Canada chairs the recently established Arctic Council (1996) composed of the eight major northern nations. One ought to expect such Canadian leadership by virtue of our immense Arctic and Subarctic territories-well over half the country. These are the homelands of our Arctic and Subarctic First Nations peoples. As they are largely federal lands, the Canadian government bears the primary responsibility in these areas for sustainable economic development, cultural well-being, and environmental stewardship. No other jurisdiction has the tax base to meet such responsibilities.

Within the Arctic Council, the Canadian government faces additional responsibilities as a partner to the Arctic Environmental Protection Strategy (AEPS), operating through four working groups (Arctic Monitoring and Assessment Program; Conservation of Arctic Flora and Fauna; Protection of the Arctic Marine Ecosystem; and Emergency Prevention, Preparedness, and Response). Canada is also a member of the nongovernmental International Arctic Science Committee (IASC), which adds research commitments. Canada also participated in the Montreal, Rio de Janeiro, and Kyoto accords, spurred by growing concern for global change which, by all forecasts, will be maximal in polar regions and could result in the dislocation and alteration of entire ecosystems. Pollution of polar regions, including food resources, is occurring by both air and sea before we have had the chance to collect adequate data on natural environments and their biodiversity. Add to this the rapid political devolution accompanying the partition of the Northwest Territories, coupled with the 
ever-growing international interest in Arctic Canada, and it is painfully ironic that Canada is in the process of dismantling its capacity to conduct Arctic research.

The question remains: has this been the deliberate choice of the political leadership, or merely a side effect of the economics of deficit reduction? We argue that it has been a negative side effect. But whatever the answer to that question, the serious setbacks to Arctic science and technology over the last decade have left us on the verge of elimination from the international arena. We do not know to what extent these actions have resulted from the lack of a Canadian Arctic Science and Technology Policy. However, in its absence, we do know that Canadians are increasingly incapable of being players on their own scientific stage. And now oversight and indecision have caught up to us!

\section{THE FEDERAL ROLE}

The most telling sign of diminishing commitment to northern research in Canada has been the progressive withdrawal, during the past decade, of all major research agencies within the Federal Government. Traditionally, these agencies have constituted the core of northern research, housed mainly in the departments of Environment, Fisheries and Oceans, and Natural Resources, with the latter playing a key role through the Polar Continental Shelf Project (PCSP). Our primary research agencies have included the Atmospheric Environment Service, the Geological Survey of Canada, the Canadian Hydrographic Service, the Canadian Wildlife Service, Health Canada, the Canadian Museum of Nature, and the Canadian $\mathrm{Mu}-$ seum of Civilization. These, along with university researchers from all disciplines, have been served logistically by the PCSP. Concurrently, the government agencies have routinely spun off substantial support for university collaborators, particularly for graduate students, in informal but effective synergies that enhanced university research capacity in the Arctic greatly beyond what would otherwise have been possible. This support also served to build numerous bridges between federal scientists and academia that facilitated cooperative programs and diminished unproductive rivalries.

In its laudable pursuit of deficit elimination, the Canadian government chose-unfortunately, from our perspective- to target its research departments for downsizing. Although it would be hard to make the case that spending on research produced our deficit, science programs, hence scientists personally, have paid a large part of the cost of reducing it. There is little point in challenging the specific decisions taken in the Federal Program Review, but we might benefit from recognizing how ineffectively the scientific community defended itself. What, for example, did Canadian university presidents, individually or collectively, contribute to the discussion about the downsizing of federal science? Did anyone point out to the decision makers that their apparent assumption about the net cost of research is incorrect? Indeed, it is increasingly recognized that research drives modern economies, and that the real cost of research left undone will be mistakes due to ignorance. Despite the long-term importance of this perspective to the nation, it has received little public discussion.

In the process of downsizing federal science, Canada has dismantled much of the infrastructure necessary to pursue and promote our national and international responsibilities in our own backyard. By eliminating hundreds of scientists from federal laboratories, we have created a science-employment environment that has diverted, and continues to divert, students away from science. No one appears to be measuring these effects, but the reality is evident. Increasingly, so many young Canadian PhDs are moving to the United States or Europe that many professors ask why they still bother training scientists at the taxpayers' expense. Someone should answer-carefully.

Arctic research was especially hard hit because it was, and is, seen to be more expensive. Many managers seem to have surrendered to this charge. Yet, we are unaware of any comparative cost-benefit studies of Arctic versus southern research. What are the long-term costs to Canada of eliminating the Arctic scientific capacity it paid to create over the last 50 years? When the inevitable next "national imperative" (an energy crisis, for example) pushes us back into the Arctic on short notice, what price will we pay for the lost corporate and scientific memories? In the natural sciences, it commonly takes an individual half a career to develop his or her best set of research questions. Persistence and continuity are indispensable.

And expense has not been the only objection. "Why work in the Arctic? No one lives there," said a former head of the Geological Survey of Canada, who-apparently on no stronger argument that this-rendered all Arctic research in that agency basically irrelevant. It is seemingly impossible to defend a program against such a stance, or at least, in this case, defence was unsuccessful. Unfortunately, our impression is that the success of Arctic research in Canada has relied all too often on the good graces of a handful of individuals who were favourably disposed towards the importance of the Arctic. Such reliance left it vulnerable to those who were not.

There is also a fundamental ethical issue here regarding Canada's relationship to its Arctic territories: is it appropriate for Canada to take an interest in Arctic science and in the environment only when opportunities for exploitation of natural resources by southern or foreign interests loom large, or only when such exploitation seems necessary for the good of the nation? This is a rather colonial attitude. Yet the current spurning by federal agencies of long-term Arctic science, not so much by choice as by economic necessity, sends exactly this message. Most appreciate that basic scientific problems, including those like global change with particularly strong and recognized Arctic relevance, can only be addressed in the long term. Still, acceptance of this fact does not secure support for the research. 
It is incumbent upon Canadians to address basic questions about the Arctic, as we remain the only nation other than Greenland with extensive High Arctic terrain within its borders. Why, for example, is it economically justifiable for other first world nations to conduct Arctic research, including a great deal in Canada, when apparently it is not so for us? To what degree can Canada afford or expect to rely on its neighbours for scientific knowledge in policy areas such as climate change and transpolar pollution? To the extent that southern Canadians are aware at all of the Arctic half of our nation, and of its environmental and cultural uniqueness, how much of this awareness is owed to decades of recruitment of young Canadians by Arctic scientists, and to their teachings, lectures, and publications? To what extent has the legitimization of Canadian sovereignty over the Arctic Archipelago arisen from the field activities of Canadian government and university scientists?

\section{UNIVERSITY RESEARCH}

In comparison to our neighbour to the south, a greater proportion of Canadian science has been done in federal laboratories. Assuming this is undesirable, a new balance might have been struck by shifting resources to the universities, using a carefully planned strategy designed not to diminish our overall capacity. Unfortunately, however, Canadian universities and federal science departments experienced downsizing simultaneously. The combined result has been a massive retirement and deportation of Canada's scientific human resource base. One can only be confused, therefore, by statements in the last federal budget that announce an impending shortfall of scientific talent a decade down the road, while deliberate steps continue to be taken to reduce Canada's science capacity.

Canadian university research in the Arctic is funded mainly by the major federal granting agencies (the Natural Sciences and Engineering Research Council, NSERC, and the Social Sciences and Humanities Research Council, SSHRC) through their Operating Grants and equivalents. The PCSP provides logistical support, which is typically of greater dollar value than granting agency support. Indeed, the granting agencies evaluate Arctic science applications on the assumption that established PCSP support will continue, and the awarding of a grant by these agencies, after rigorous review in a very competitive system, is an indication, to PCSP among others, that the science is worthy of support. The ongoing removal or serious reduction of PCSP support (including closure of Tuktoyaktuk base) will render some programs financially unfeasible, jeopardizing their NSERC/SSHRC support. Meanwhile, NSERC and SHHRC have had their budgets seriously diminished, their helpful "northern supplements" long since ended, and many grants have been terminated. Although this year's federal budget made a commitment to begin restoration of funding levels to these agencies, the typical operating grant (commonly below $\$ 30000$ and rarely above $\$ 50000$ for scientists with Arctic field programs) cannot absorb the logistical costs traditionally born by PCSP. And so it spirals. Canadian university research in the Arctic, already at a low level, will essentially disappear unless funding and support are increased. It is that simple.

The funding crunch for university research has resulted in a steep decline in applications for logistical support to PCSP during the 1990 s, from a high of 70 projects down to c. 40 this year. Government projects have declined even more severely, by close to 50\%. In 1980, PCSP actually supported 166 field parties and this number grew to a high of 250 parties during that decade (George Hobson, pers. comm. 1998).

In the meantime, our established community of northern scientists is aging and retired, or retiring younger. Upcoming researchers face fewer opportunities. As confidence in Canadian prospects of funding and logistical support for northern research continues to erode, it comes as no surprise that few will risk their futures by investing in northern careers. Hence, academic recruitment in Canada for northern research has reached alarmingly low levels and a compelling option, if not a necessity, for anyone with northern interests is to head to the United States or Europe. Indeed, few Canadian universities are recruiting Arctic specialists today, possibly because the chances of building a program attractive to the university are so daunting. Or our southern universities themselves may simply have lost interest.

Canada now faces a crisis in northern research (and perhaps research in general) that, if left unchecked, will ensure our failure to train and support the next generation of scientists and lead to a collapse of Canadian scientific sovereignty. We will then be unable to meet basic national obligations to adequately monitor, manage, and safeguard our environment, let alone to take a leadership role or to strongly contribute to issues of international importance. It is already much more common to hear science about Canada from others at international meetings than it is to hear Canadian science. But, to be perfectly clear about what we think is wrong here, it is not the attention of our neighbours and friends. Indeed, we suspect that Americans who are sensitive to this issue go out of their way to include Canadians in their programs, allowing the problem to seem less severe than it is.

\section{LEARNING FROM THE FRIENDLY GIANT}

It is a sad but recurrent reality that to get the attention of Canadian policy makers one must often resort to embarrassing comparisons with our American neighbours. The need to do so is especially aggravating when it deals with such a fundamental issue of our Canadian identity. Granted, we occasionally forget the words to our own national anthem, but have we also forgotten where we live? Why 
must Canadians continually hound their government to provide the support necessary to pursue what should be an inherent and irresistible interest in our own country? In a letter to the Globe and Mail, in response to the country's predisposition to ignore its Arctic, England wrote that, like Dracula, Canada runs the risk of standing in front of its own mirror and failing to appear.

While Canada has been dismantling Arctic research, the United States has demonstrated a renewed commitment through rigorous legislation, strong funding, and required interagency cooperation. A comparison of the two countries in Arctic matters reveals American vision towering over Canadian indecision and parsimony, and the consequence is opportunity and leadership vs. unemployment and ever-dwindling significance. Surely this cannot be because Arctic research is less relevant to Canada! It is the saddest form of flattery when we are informed that the recent American initiative arose from the pleas of American scientists, familiar with PCSP, who sought, in part, to emulate our success in Arctic research.

In northern matters, Canada suffers even more from a lack of leadership than from a lack of resources. Therefore, given Canada's reluctance to take a fully integrated, leadership role in the Arctic, it is instructive to look closely at what is clearly an extremely progressive American lead. Afterwards, we will discuss some recent developments that show promising signs of Canada's renewed commitment to the North, at least at the political level, and how we propose that this should be brought to further fruition.

The United States took an immense step forward when it passed the Arctic Research and Policy Act of 1984 (amended 1990) (See IARPC, 1997: Appendix E). In so doing, the United States recognized itself as an Arctic nation with strong strategic, economic, social, scientific, and international interests pertaining to "all United States and foreign territory north of the Arctic Circle" (SEC. 112). Passed before the end of the Cold War, this Act addresses a wide array of issues and includes an assigned and dedicated budget. It speaks about the fact that "Federal Arctic Research is fragmented and uncoordinated" (SEC. 102.(a)11) and that "improved logistical coordination and support for Arctic research...is necessary" (SEC. 102.(a) 12). The Act set in motion a progressive infrastructure, establishing an Arctic Research Commission to promote research and recommend policy. The Commission was complemented by the Interagency Arctic Research Policy Committee which, in consultation with the Government of Alaska, its public interests groups, and the private sector, established a five-year plan to implement policy within one year after enactment (sent to Congress, July 1987). Since then, the plan has been revised every two years. Biennial statements seek to ensure the pursuit of basic principles of the U.S. Arctic Research and Policy Act. For example, the January 1993 biennial statement identified the need to improve the nation's Arctic engineering capabilities through coordinated and continuing programs at universities and national laboratories. Finally, the Act established the U.S. National Science Foundation (NSF) as the "lead agency for implementing Arctic research policy" (SEC. 102.(b)3). The NSF subsequently created the Arctic System Science (ARCSS) program.

Anyone concerned with the plight or future direction of northern research in Canada should read the Fifth Biennial Revision (1998-2002) of the U.S. Arctic Research Plan (IARPC, 1997). It is evident that it is "the result of an extensive process of planning, consultation and revision" (p. 4). The Plan outlines national needs (nonrenewable and renewable resources, global change, social and environmental issues), a broad range of special focus multiagency research programs, and a host of agency programs. The total interagency funding for fiscal year 1997 was US $\$ 172$ million, and for 1998 it is US\$156 million. A selection of agencies includes the Department of Defence, the Department of the Interior, Department of Energy, National Aeronautics and Space Administration, and the National Science Foundation, which includes the Office of Polar Programs. The multiagency programs stand out for their breadth and depth, and include issues such as risks to the environment and people in the Arctic, surface heat budget of the Arctic Ocean, Beringian systems studies, and Arctic data and information. The multiagency Beringian study could just as easily describe the Canadian Arctic Archipelago, emphasizing that this region is "emerging as a major international arena for interdisciplinary study of scientific issues and global change with historical and modern perspectives" (p. 23). It emphasizes the fundamental importance of "baseline data and monitoring" (p. 24).

The multiagency collaboration also identifies the importance of Arctic data and information, participating in the Arctic Environmental Data Directory (AEDD), an IASC initiative which resides on the World Wide Web, linking more than 50 other Arctic data and information sources. The AEDD Working Group is further connected with the United Nations Environment Program Global Resources Information Database in Arendal, Norway. Together they have established compatible directories for an international Arctic Data Directory. Efforts are being made to establish a third node in Moscow. These are important initiatives, as Arctic information databases and CD-ROMs rapidly proliferate and require collation and simplified access. The U.S. Polar Information Working Group is also attempting to provide a single, user-based service for U.S. Arctic and Antarctic scientific communities that require the matching of information sources and needs. This effort includes a wide range of U.S. universities (Alaska, Dartmouth, Colorado, Ohio State, all notable Arctic science schools) together with other organizations like the Arctic Research Consortium of the United States. A veritable plethora of acronyms (Appendix A of the Fifth Biennial Revision) attests to the profusion of arctic agencies and information in the United States.

Agency programs within the Fifth Biennial Revision of the Plan outline new opportunities for Arctic research 
(remote sensing, U.S.-Russian collaboration, etc.) and scientific programs dealing with the Arctic Ocean and marginal seas, atmosphere and climate, land and offshore resources, land-atmosphere-water interactions (glaciology, hydrology, and permafrost), engineering and technology, social sciences (U.S. Man and the Biosphere Program, Human Dimensions of Global Change Program, cultural resources, etc.), and health.

The main text of the Fifth Biennial Revision ends with a section on logistics that reduces Canadian worries about PCSP to black comedy. The Plan starts off unabashedly stating that "it reaffirms that an ice-capable research ship should be operated as a national facility for both the Federal and academic communities," adding that "a research vessel providing all-season access to the Arctic region is essential for many research requirements" (p. 47). It also notes that in 1994 the U.S. Arctic Research Commission implemented a Memorandum of Agreement to lay the foundations for "annual nuclear submarine cruises dedicated to science in the Arctic Ocean....to conduct unclassified experiments selected from competitive proposals.... with the costs being shared by the U.S. Navy (which will provide the Arctic-capable submarine at no cost to the science community)" (p. 47). Satellite surveillance using a wide range of technologies is available for such interests as worldwide sea ice extent (on a weekly basis), and land-based facilities are available from local agencies in Greenland, the Canadian High Arctic (PCSP receives mention), and the Norwegian Polar Institute in Svalbard.

Simply put, the scope, integration, and support for Arctic research in the United States is enormous. And make no mistake, it is based rigorously and thoughtfully upon established principles and objectives. There is no indecision here! No suffocating parsimony. It seems to us that Canada at this point has two choices: rely entirely on the United States for all Arctic science (contracts would probably be welcomed) or seriously acknowledge its own geographic identity and behave accordingly.

\section{WHITHER PCSP: NOT AFFORDABLE AT 20 CENTS PER CAPITA PER YEAR!}

It is important here to return to and to make clear the plight of the Polar Continental Shelf Project. It highlights the contrast between U.S. and Canadian Arctic strategies, and it effectively shows the urgency and the extent of our crisis.

PCSP, currently celebrating its 40th anniversary, was established by Act of Parliament in 1958, as part of Prime Minister Diefenbaker's "northern vision." It was visionary, it has been gloriously successful, it has fostered most of Canadian Arctic research and assisted non-Canadian research. PCSP started out as a bold and innovative solution to the scientific field requirements for exploring the vast and diverse Canadian Arctic Archipelago and adjacent continental shelf. Its successes, ingenuity, and efficiency are a monument to the dedicated efforts of its directors on behalf of Canadian polar science. It is now entirely a logistical operation, but a seasoned one, based in Ottawa with facilities in Resolute Bay (High Arctic) and Tuktoyaktuk (western Arctic; now dormant). Each spring and summer it has operated chartered aircraft (Twin Otters, helicopters) that provide the coordinated logistical support for staging and evacuating fly (tent) camps widely dispersed throughout the northern mainland and islands. Principally, it has operated north of the Arctic Circle. PCSP supports scientists from both universities and government research agencies who, for the most part, live frugally while investigating everything from archaeology to zoology, to borrow George Hobson's expression. At its peak during the 1970s and 1980s, PCSP had a budget of around Cdn $\$ 6$ million, largely dedicated to logistics. It was administratively light, with a Director and couple of base managers who quickly established an international reputation for remarkable efficiency. For virtually every client, it epitomized what a well-run government agency could be. It has been audited several times by the Treasury Board and received exemplary reviews. Only three years ago, it was further evaluated for its perceived usefulness to its clients: the government evaluators reported that they had never seen such high praise in 30 years of assessment! Despite such glowing recommendation, despite its extremely modest budget ( 20 cents per Canadian per year at its peak), despite being indispensable to its clients, despite the fact that it makes a Canadian presence in Arctic research possible, and despite its astonishing success in safety and efficiency, its budget has been cut progressively and it now struggles to survive.

The tenuous support and persistent uncertainty that has plagued most Arctic scientific careers in Canada makes a fascinating story in itself. Hence, battling for the protection of PCSP has become a distraction and a necessary obligation. On two separate occasions, lobbying by England (and others) of two Cabinet Ministers (Deputy Prime Minister Don Mazenkowski on PCSP's 30th anniversary, 1988; and Minister Anne McLellan of Natural Resources Canada, during Program Review, 1996) facilitated temporary increases or reprieves for its budget. These interventions by Ministers attest to their perceptiveness and willingness to acknowledge and validate Canada's Arctic mandate. They readily acknowledged the necessity of a supporting agency like PCSP for fulfilling our national responsibilities toward the Arctic. Furthermore, parliamentary documents are filled with wonderfully supportive statements about the intrinsic value and necessity of Arctic research to Canada (see, e.g., Canada and the Circumpolar World, Report of the House of Commons Standing Committee on Foreign Affairs and International Trade, April 1997; and the Third Conference of Parliamentarians of the Arctic Region Conference Statement, April 1998). It appears to us, therefore, that the political leadership is willing to support Arctic research, but that there has not been similar consistency within the civil service. 
Despite the political interest, by 1999 PCSP's budget for its entire Arctic field operation will drop to about Cdn\$1 million (US\$710 000; approaching one-sixth of peak funding, without correction for inflation). The NSFfunded PALE Project (Paleoecology of Arctic Lakes and Estuaries) has a Steering Committee budget of US $\$ 600000$. Soon PCSP will be able to offer only a meagre Cdn $\$ 250000$ (US\$178 000) for the entire Canadian university community. About one-third its level of only three years ago, this amount would fall within the range of a single modest NSF project. A recent report from an Arctic institute at an American university lists nearly US $\$ 20$ million in current research grant holdings for that institution. At $\mathrm{Cdn} \$ 1$ million per year, PCSP's logistical operation costs Canadians about 3 cents per citizen per year, less than the GST on a 50-cent chocolate bar! Compared to the present U.S. Arctic research commitment, PCSP, which started out so bold and gave us such pride, now looks like a rusted-out VW Beetle with four flat tires eclipsed by the gleaming technology of the space shuttle. This contrast cannot be dismissed as due solely to economies of scale; to a large degree, it is due to Canada's economy of self-betrayal.

The plight for government research agencies, which previously received full logistical support for much or all of their Arctic programs from PCSP, is equally severe. Traditionally, awards to these agencies did not include funds to cover logistical costs because such costs would be covered by PCSP. Now these agencies find their own budgets severely reduced and PCSP with minimal resources. These agencies are now required to provide 50 $100 \%$ cost recovery, varying from project to project, and there is no relief in sight. The effect is the same as for the universities. Effectively, PCSP is being forced to move from the role of research facilitator to that of travel agent. It is also moving toward an unattractive ratio of budget allocated for logistical support to budget allocated for overhead cost, despite cutting the latter to the bone. This is not a justifiable position for an agency whose sole raison d'être is logistical support and which plays neither a research nor a policy role.

The crisis for Arctic research in Canada is thus obvious. The overall effect of our collective failure, however, will also be much greater than the straight percentage reduction in support because the overall reduction in the synergy and calibre of Arctic research will be much greater as critical mass is lost. The political danger here is that it becomes easy to misconstrue the diminished ranks of university applicants and number of government projects as expressions of diminished scientific interest and low relative importance of Arctic science to the nation. Nothing could be further from the truth, but saying this will not solve the problem.

\section{LOOKING AHEAD}

What we present here echoes the thoughts of many Arctic researchers who are struggling to find signs of hope on Canada's horizon. The Government of Canada strongly supported the establishment of the Arctic Council, and the government's commitment to conservation under the Arctic Environmental Protection Strategy clearly requires an ongoing contribution from Canadian scientists. The Standing Committee on Foreign Affairs and International Trade (SCFA) recommended that "the Government commit to maintain, and seek to increase, support for basic Arctic science and research as an important element of circumpolar cooperation." It effectively sets aside the "expense" argument in stating that "the cost of Canada"s [Arctic] research was never high in comparison to the amounts spent by other Arctic states" (SCFA, 1997:180). It validated the argument advanced to it by Michel Allard (SCFA, 1997:180) that "Canadian scientific research in the North produced, especially from 1950 to $1989, \ldots$ spectacular results with investments that were in fact far inferior to those made by the major powers."

Canada also took the initiative of establishing a Polar Commission in 1991 and appointing an Arctic Ambassador in 1993. The Polar Commission reports to the Minister of Indian Affairs and Northern Development and is responsible for fostering the development of knowledge about the polar regions in Canada, much like the U.S. Arctic Research Commission. Although it has a budget of about $\$ 1$ million per year for this purpose, it appears to lack the scientific depth of the U.S. Interagency Arctic Research Policy Committee. The Arctic Ambassador resides in Foreign Affairs and reports to both the Minister of Foreign Affairs and International Trade and the Minister of Indian Affairs and Northern Development. The post is connected to the international political forum and it is the first chair of the Arctic Council.

There are many other players in the Canadian Arctic research community. The Association of Canadian Universities for Northern Studies (ACUNS) promotes northern education, organizes a biennial student workshop (last December, brimming with capable enthusiasm), has a small fund for scholarships, and-increasingly-lobbies all levels of government to reinvigorate Arctic research. The Northern Science Training Program of the Department of Indian Affairs and Northern Development has opened the door to the Arctic for numerous students by awarding small grants. The Royal Canadian Geographical Society also provides northern student scholarships, and alerts the country about northern issues through its widely subscribed magazine, Canadian Geographic, and through the sponsorship of cross-country lectures. Research and scholarly institutes at Canadian universities (Canadian Circumpolar Institute, University of Alberta; Centre d'études nordiques, Université Laval; The Arctic Institute of North America, University of Calgary) play important roles, foremost among which is the publication of this journal, but they are smaller than most of their American counterparts (e.g., Institute of Arctic and Alpine Research, University of Colorado). Canada continues to maintain a very active nongovernmental watchdog agency concerned 
with northern issues through the Canadian Arctic Resource Committee, which has been a vigilant and effective lobbyist for several decades. Nonetheless, much of this activity throughout Canada remains diffuse and poorly coordinated. Furthermore, the leadership role of the Polar Commission has not been "perceived as a legitimate voice of those interested in northern research" (SCFA, 1997:187); and its current ineffectiveness in promoting national Arctic interests has brought widespread disappointment. However, its mandate has been extended in the latest federal budget and its potential for leadership persists.

So where can we go from here? Clearly it is intolerable to languish in our present state. Therefore, as an idea for discussion by the Canadian Arctic science community, we resurrect here the proposal that Canada establish a Canadian Polar Institute. This institute would effectively house and coordinate our national goals and expertise in Arctic social and natural science, technology, logistics (PCSP), and policy. It should be a real (as opposed to a virtual) institute, where people can gather and interact. It should be established by an Act of Parliament, and set firmly upon principles and objectives included in an Arctic Science and Technology Act. International cooperation with other Arctic institutes and agencies would be an implicit objective. We can see no other way to safeguard Arctic research and its essential infrastructures in times of intense funding stress. A Canadian Polar Institute could also play an indispensable role in planning and coordinating future Arctic research.

In 1985, the Honourable David Crombie, then Minister of Indian Affairs and Northern Development, called for consideration of a National Polar Institute. A working group consisting of Dr. Fred Roots, Dr. Peter Adams, Mr. Peter Burnet, and Mr. Mark Gordon carefully considered the state of Canadian polar research at that time, as well as the advantages and disadvantages of the Minister's proposal. In their report (Adams et al., 1987), they thoroughly identified the problems and recommended, instead of a scientific institute, a Canadian Polar Commission, which was subsequently established. We do not suggest for a moment that this was an error of judgement. However, the fact that the problems that they and the research community recognized a decade ago have so intensified since illustrates that a sufficient solution remains to be found. The situation today is different from that of 1985 primarily in the reduced size of the research community and in the perilous state of PCSP. An idea that came from Cabinet in 1985 surely is worth exploring again, now that the needs are all the more evident.

We realize that a new institute would require new funding and that the idea could most easily be killed by bureaucratic turf wars. There are, however, ways to avoid this. Although a range of models should be considered, an attractive one is provided by Canada's two oceanographic institutes: the Bedford Institute of Oceanography (Dartmouth, Nova Scotia), and the Institute of Ocean Sciences (Sydney, British Columbia). Although housed in the Department of Fisheries and Oceans, the Geological Survey of Canada (Natural Resources Canada) maintains divisions at both institutes, apparently without loss of institutional integrity. Like oceanographic research, polar research is unified by its special logistical needs and by its strongly interdisciplinary composition. A Canadian Polar Institute could bring together many polar science and policy groups, without any rigid requirement of being allinclusive at the expense of existing federal agencies. The challenge would be to construct an institute with sufficiently "porous walls" to optimize interaction between the institute and universities. Ideally, it would be the venue of choice for Canadian and international scholars on sabbatical leave, for private sector scientists working on Arctic problems, and for researchers from northern communities.

We emphasize the need to collect, coordinate, and streamline existing Arctic interests in a new Polar Institute. Coordination of logistics must now be matched by coordination of research to demonstrate optimum efficiency. To facilitate the greatest efficiency and expertise in Canadian Arctic interests, the Institute should house both the PCSP and the Polar Commission. PCSP could then be fundamentally rejuvenated and tethered to a strong, mandated, research agenda. The Polar Commission would continue to act as the nation's premiere Arctic-Antarctic policy adviser, and it would continue to promote public awareness of the North. The Polar Commission would have the added advantage of continuous and direct access to an active scientific community. Similarly, the Arctic scientific community would benefit from the broader perspectives of the Polar Commission, including its First Nations members, who could strongly influence research agendas. Finally, the Institute would promote appropriate linkages with Canada's three northern territories and with First Nations organizations in the arctic regions of the provinces, primarily Labrador and arctic Quebec.

Canada cannot afford to stand disorganized in the midst of a more progressive international community while holding jurisdiction over such a large proportion of Arctic land and sea. As a member of the Arctic Council and participant in the Arctic Environmental Protection Strategy, Canada will increasingly be expected to contribute to the gathering and dissemination of knowledge, to ensure stewardship of its environment, and to provide the best service to its Arctic citizens, who are now divided among seven territorial and provincial jurisdictions. To accomplish this, we must first set in place the funding and the infrastructure to address challenging, long-term issues (e.g., global change, polar pollution) and to train future Arctic scientists. Therefore, Canada needs a thoughtful and progressive Arctic Science and Technology Act. We strongly recommend that such an Act embody within it a Canadian Polar Institute and that interested Canadians be widely and extensively consulted in drafting the Act. Unless we restructure our Arctic programs, we will continue the wasteful cycle of building, abandoning, forgetting, and rebuilding. The risk of further delay is total collapse of our 
already tenuous domestic capacity in Arctic research. But nothing will happen unless those who comprise the Arctic research community make their voices heard by presenting politically acceptable solutions.

Last December, Canada lost one of its most prominent Arctic ecologists when Steve Zoltai passed away. All of us knew Steve, and John England, together with colleague Peter Kershaw, was honoured to sit with him only weeks before, listening to him overcome his advanced illness to speak passionately about these very issues. Steve made one particularly moving point when he lamented that an American would be responsible for producing the Canadian component of the new Circumpolar Arctic Vegetation Map. This is not to imply that the American does not have the right and the knowledge to do this; rather, it highlights our shortage of enlightened self-interest and our seemingly perpetual inability to provide even basic responses to international efforts - in this case, at a scale of 1:7 500000 ! $\mathrm{We}$, and our colleagues, share Steve's discouragement about the persistent and lamentable indifference to the North which, if left unattended, will go a long way toward stifling our national identity. It is time for the Canadian government to step to the plate and face north!

\section{REFERENCES}

IARPC (INTERAGENCY ARCTIC RESEARCH POLICY COMMITTEE). 1997. U.S. Arctic Research Plan, Biennial Revision: 1998-2002. Arctic Research of the United States $11.75 \mathrm{p}$.

ADAMS, W.P., BURNET, P.F., GORDON, M.R., and ROOTS, E.F. 1987. Canada and polar science. Ottawa: Circumpolar and Scientific Affairs Directorate, Department of Indian and Northern Affairs. 129 p.

SCFA (HOUSE OF COMMONS STANDING COMMITTEE ON FOREIGN AFFAIRS AND INTERNATIONAL TRADE). 1997. Canada and the circumpolar world: Meeting the challenges of cooperation into the twenty-first century. Second Session of the Thirty-fifth Parliament. Ottawa: House of Commons. 316 p.

John H. England is a professor in the Department of Earth and Atmospheric Sciences, University of Alberta.

Arthur S. Dyke is a geologist who lives in Pakenham, Ontario. Gregory H.R. Henry is a professor in the Department of Geography, The University of British Columbia. 